\title{
Application of Cerium (IV) as an Oxidimetric Agent for the Determination of Ethionamide in Pharmaceutical Formulations
}

\author{
Kanakapura Basavaiah, ${ }^{1}$ Nagib A. S. Qarah, ${ }^{1}$ and Sameer A. M. Abdulrahman ${ }^{2}$ \\ ${ }^{1}$ Department of Chemistry, University of Mysore, Manasagangotri, Mysore 570 006, India \\ ${ }^{2}$ Department of Chemistry, Faculty of Education and Sciences Rada'a, Al-Baydha University, Al Bayda, Yemen
}

Correspondence should be addressed to Kanakapura Basavaiah; kanakapurabasavaiah@gmail.com

Received 21 July 2016; Accepted 22 September 2016

Academic Editor: Rama Pati Tripathi

Copyright (C) 2016 Kanakapura Basavaiah et al. This is an open access article distributed under the Creative Commons Attribution License, which permits unrestricted use, distribution, and reproduction in any medium, provided the original work is properly cited.

\begin{abstract}
Two simple methods are described for the determination of ethionamide (ETM) in bulk drug and tablets using cerium (IV) sulphate as the oxidimetric agent. In both methods, the sample solution is treated with a measured excess of cerium (IV) solution in $\mathrm{H}_{2} \mathrm{SO}_{4}$ medium, and after a fixed standing time, the residual oxidant is determined either by back titration with standard iron (II) solution to a ferroin end point in titrimetry or by reacting with o-dianisidine followed by measurement of the absorbance of the orange-red coloured product at $470 \mathrm{~nm}$ in spectrophotometry. In titrimetry, the reaction proceeded with a stoichiometry of 1:2 (ETM: Ce $(\mathrm{IV})$ ) and the amount of cerium (IV) consumed by ETM was related to the latter's amount, and the method was applicable over $1.0-8.0 \mathrm{mg}$ of drug. In spectrophotometry, Beer's law was obeyed over the concentration range of $0.5-5.0 \mu \mathrm{g} / \mathrm{mL}$ ETM with a molar absorptivity value of $2.66 \times 10^{4} \mathrm{~L} /(\mathrm{mol} \cdot \mathrm{cm})$. The limits of detection (LOD) and quantification (LOQ) calculated according to ICH guidelines were 0.013 and $0.043 \mu \mathrm{g} / \mathrm{mL}$, respectively. The proposed titrimetric and spectrophotometric methods were found to yield reliable results when applied to bulk drug and tablets analysis, and hence they can be applied in quality control laboratories.
\end{abstract}

\section{Introduction}

Ethionamide (ETM), chemically known as 2-ethylthioisonicotinamide, is a second-line orally administered drug that is used for the treatment of multidrug resistant tuberculosis [1] . The drug has been in use since 1960s, because it is cheap, easily available, relatively nontoxic, and efficacious [2]. ETM is a structural analog of isoniazid $[3,4]$ and is found to inhibit mycolic acid biosynthesis [5] with good bioavailability [6].

The drug is official in the British Pharmacopoeia [7], which describes a titrimetric assay with acetous perchloric acid in anhydrous acetic acid medium. Other methods based on fluorometric [8] and spectrophotometric [9-19] techniques have been reported for its assay in pharmaceuticals. Other than the official method [7], three more titrimetric methods are found in the literature for the assay of ETM in pharmaceuticals [20-22]. Reddy et al. [20] titrated ETM with $\mathrm{N}$-bromosuccinamide using several anthraquinones as indicators. The drug in $25-500 \mu \mathrm{mol}$ levels was assayed by Ciesielski et al. [21] by titrating it with iodine in alkaline medium.
Employing AgS-ion-selective electrode as the sensor, Obtemperanskaya et al. [22] have reported a micro method by titration of the drug solution with $0.01 \mathrm{M} \mathrm{AgNO}_{3}$. The titrant used in the previously reported method [20] is unstable and requires daily standardization whereas the method employing membrane electrode [22] is tedious and time-consuming. It is desirable that the methods used in routine analysis should be simple and rapid with minimum experimental operations. Though ETM is prone to oxidation, a stable and strong oxidant such as cerium (IV) did not figure among the several titrimetric or spectrophotometric reagents that have been employed earlier for the assay of ETM. The reported spectrophotometric methods suffer from some disadvantages such as need for longer contact time, $\mathrm{pH}$ adjustment, multistep reactions, extraction step, and dependence on critical experimental variables.

In this paper, we describe two simple, rapid, and sensitive methods for the determination of ETM in pharmaceuticals using cerium (IV) as the oxidant. The methods are based on the oxidation of ETM by a measured excess of cerium (IV) 
in $\mathrm{H}_{2} \mathrm{SO}_{4}$ medium followed by the determination of the unreacted oxidant either by titration with iron (II) visually (titrimetry) or by reacting it with ortho-dianisidine and measuring the absorbance of the orange-red coloured product at $470 \mathrm{~nm}$ (spectrophotometry). The two methods were found to be fairly accurate and precise in addition to being more sensitive compared to the previously reported methods.

\section{Materials and Methods}

2.1. Materials. Pharmaceutical grade ethionamide, certified to be $99.84 \%$ pure, was received as gift from Panacea Biotic Ltd. and used as received. Three brands of tablets, namely, Ethide (Lupin Ltd., Mumbai, India), Ethiokox (Radicura Private Ltd., New Delhi, India), and Myobid (Panacea Biotic, New Delhi, India) labeled to contain $250 \mathrm{mg}$ of ETM per tablet, were purchased from local commercial sources.

2.2. Apparatus. A Systronics model 166 digital spectrophotometer (Systronics, Ahmedabad, Gujarat, India) with matched $1 \mathrm{~cm}$ quartz cells was used for absorbance measurements.

2.3. Chemicals and Reagents. All chemicals used were of analytical reagent grade. Double distilled water was used throughout the investigation.

Cerium (IV) Solution (0.01M). An approximately $0.01 \mathrm{M}$ cerium (IV) solution was prepared by dissolving the required quantity of cerium (IV) sulphate (Loba Chemie, Mumbai, India) in $0.5 \mathrm{M} \mathrm{H}_{2} \mathrm{SO}_{4}$ with the aid heat and filtered using glass wool; the solution was standardized [23] with pure ferrous ammonium sulphate (Loba Chemie, Mumbai, India) and used in titrimetry. The stock standard solution was diluted appropriately with $0.5 \mathrm{M} \mathrm{H}_{2} \mathrm{SO}_{4}$ to get $100 \mu \mathrm{g} / \mathrm{mL}$ cerium (IV) for use in spectrophotometry.

Ferrous Ammonium Sulphate, FAS $(0.01 \mathrm{M})$. It is prepared by dissolving the calculated amount of the chemical in water in the presence of few drops of dilute $\mathrm{H}_{2} \mathrm{SO}_{4}$ and standardized using pure potassium dichromate [23].

Ortho-Dianisidine, ODS (0.05\%). It is prepared by dissolving the calculated amount of the chemical (Loba Chemie, Mumbai, India) in ethanol.

Sulphuric Acid (5M). Concentrated acid (98\%; sp. gr. 1.82, Merck, Mumbai, India) was diluted appropriately with water to get $5 \mathrm{M}$ acid and used in spectrophotometry, and the same solution was diluted to $2 \mathrm{M}$ level for use in titrimetry.

Ferroin Indicator. Prepared by dissolving $0.695 \mathrm{~g}$ of $\mathrm{FeSO}_{4} \cdot 7 \mathrm{H}_{2} \mathrm{O}$ (Alpha Chemicals, India, assay 99\%) and $1.485 \mathrm{~g}$ of 1,10-phenanthroline monohydrate (Qualigens Fine Chemicals, Mumbai, India, assay 100\%) in water and diluted to volume in a $100 \mathrm{~mL}$ calibrated flask.

Standard Drug Solution. A solution of $1 \mathrm{mg} / \mathrm{mL}$ ETM was prepared by dissolving $250 \mathrm{mg}$ of pure drug in $0.1 \mathrm{M} \mathrm{H}_{2} \mathrm{SO}_{4}$ and diluted to volume in a $250 \mathrm{~mL}$ calibration flask with the same solvent and used in titrimetric assay. The stock solution was diluted stepwise with $0.1 \mathrm{M} \mathrm{H}_{2} \mathrm{SO}_{4}$ to get a working concentration of $20 \mu \mathrm{g} / \mathrm{mL}$ for spectrophotometry.

\subsection{General Procedures}

2.4.1. Titrimetric Assay. A $10 \mathrm{~mL}$ aliquot of the drug solution containing $1.0-8.0 \mathrm{mg}$ of ETM was placed in a $100 \mathrm{~mL}$ titration flask and acidified with $5 \mathrm{~mL}$ of $2 \mathrm{M} \mathrm{H}_{2} \mathrm{SO}_{4}$. Ten milliliters of $0.01 \mathrm{M}$ cerium (IV) solution was pipetted into the flask and the contents were mixed well. After a standing time of $5 \mathrm{~min}$, the residual oxidant was titrated with ferrous ammonium sulphate (FAS) solution using a drop of ferroin indicator. A blank titration was performed, and the amount in the aliquot was computed from the amount of cerium (IV) that reacted with ETM.

2.4.2. Spectrophotometric Assay. Different aliquots (0.0, 0.25 , $0.5, \ldots, 2.5 \mathrm{~mL}$ ) of $20 \mu \mathrm{g} / \mathrm{mL}$ ETM solution were accurately transferred into a series of $10 \mathrm{~mL}$ calibrated flasks. To each flask $3 \mathrm{~mL}$ of $5 \mathrm{M} \mathrm{H}_{2} \mathrm{SO}_{4}$ was added, followed by $1 \mathrm{~mL}$ of $100 \mu \mathrm{g} / \mathrm{mL} \mathrm{Ce}(\mathrm{IV})$ solution. The contents were mixed well and the flasks were set aside for $10 \mathrm{~min}$. Finally, $1 \mathrm{~mL}$ of $0.05 \%$ ODS solution was added to each flask, and the volume was brought to the mark with $5 \mathrm{M} \mathrm{H}_{2} \mathrm{SO}_{4}$. The absorbance of each solution was measured after $5 \mathrm{~min}$ at $470 \mathrm{~nm}$ against a water blank.

A standard graph was prepared by plotting the difference between blank absorbance and sample absorbance as a function of concentration of the drug, and the concentration of the unknown was computed using the regression equation derived from the absorbance-concentration data.

2.4.3. Procedure for Tablets. Twenty tablets were weighed accurately and ground into a fine powder. A portion of the powder equivalent to $100 \mathrm{mg}$ of ETM was weighed accurately and transferred into a $100 \mathrm{~mL}$ calibrated flask, $60 \mathrm{~mL}$ of $0.1 \mathrm{M}$ $\mathrm{H}_{2} \mathrm{SO}_{4}$ was added, and the content was shaken for $20 \mathrm{~min}$; the volume was diluted to the mark with $0.1 \mathrm{M} \mathrm{H}_{2} \mathrm{SO}_{4}$, mixed well, and filtered using Whatman 42 filter paper. The filtrate $(1 \mathrm{mg} / \mathrm{mL}$ in ETM) was used in assay by titrimetry, and the same solution was diluted to $20 \mu \mathrm{g} / \mathrm{mL}$ level for assay by spectrophotometry.

2.4.4. Procedures for Method Validation. The assay validation procedures were carried out according to the current $\mathrm{ICH}$ guidelines [24], which include linear range, limits of detection (LOD) and quantification (LOQ), precision, accuracy, robustness, ruggedness, and selectivity.

(1) Linear Range, $L O D$, and $L O Q$. In titrimetry, the range was determined by titrating different amounts of drug under optimized conditions and the " $n$ " value (number of moles of cerium (IV) reacting with each mole of ETM) was calculated. In spectrophotometry, the linearity was assessed by the calibration graph, which was constructed by plotting the absorbance versus concentration of ETM and the regression equation was calculated. The LOD and LOQ were calculated using the relation $k s / b$, where $k=3$ for LOD and 10 for 
LOQ, $s$ is the standard deviation of seven blank absorbance readings, and $b$ is the slope of the calibration curve [25].

(2) Accuracy and Precision. The accuracy of the proposed methods was determined on the basis of the difference in mean calculated and amount/concentration taken (\% deviation from the actual concentration, DFA); and the precision was determined by calculating the intraday and interday relative standard deviation. These were computed by analyzing standard solution of ETM at three levels seven times on the same day (intraday) and on five consecutive days (interday).

(3) Robustness and Ruggedness. Robustness was evaluated by assaying the standard solutions after slight but deliberate variations in the analytical conditions like contact time and volume of $\mathrm{H}_{2} \mathrm{SO}_{4}$. Ruggedness, on the other hand, was assessed by a study in which the determination was performed by three analysts and also by a single analyst using three different burettes (titrimetry) and cuvettes (spectrophotometry).

(4) Selectivity. The placebo blank and synthetic mixture were analyzed by the developed methods and the results compared with those obtained on standard drug solution. A placebo blank of the composition: $20 \mathrm{mg}$ talc, $30 \mathrm{mg}$ starch, $20 \mathrm{mg}$ sucrose, $20 \mathrm{mg}$ lactose, $10 \mathrm{mg}$ gelatin, $20 \mathrm{mg}$ sodium alginate, $30 \mathrm{mg}$ magnesium stearate, and $20 \mathrm{mg}$ methyl cellulose was prepared by homogeneous mixing in a mortar. Ten milligrams of placebo was placed in a $50 \mathrm{~mL}$ calibration flask and its extract was prepared as described under Section 2.4.3. To $50 \mathrm{mg}$ of the placebo blank prepared above, $100 \mathrm{mg}$ of pure ETM was added and mixed thoroughly and the mixture was quantitatively transferred into a $100 \mathrm{~mL}$ calibrated flask; and then steps described under Section 2.4.3 were followed.

(5) Application to Tablets. Tablet solution prepared as described earlier was subjected to analysis by applying the developed procedures by taking $5 \mathrm{~mL}$ aliquot (titrimetry) and $3 \mathrm{~mL}$ aliquot (spectrophotometry) in five replicates, and the measured analytical signal was used to calculate the percent of the label claim. For comparison, the tablet extract in glacial acetic acid was titrated potentiometrically with acetous perchloric acid [7].

(6) Recovery Test. Preanalyzed tablet powder was spiked with pure drug at three levels and the total quantity of the drug was calculated, and finally the percent recovery of the pure drug added was calculated.

\section{Results and Discussion}

Cerium (IV) sulphate is a chemical compound which is frequently used as an oxidizing agent in titrimetric methods. The orange colour of cerium (IV) ion is reduced to the colourless cerium (III) ion.

$$
\mathrm{Ce}^{+4}+\mathrm{e}^{-} \rightleftharpoons \mathrm{Ce}^{+3}
$$

Cerium (IV) is a powerful oxidizing agent which finds immense applications in the analysis of several pharmaceuticals [26-32]. This property of the oxidant was used in the present assay. The drug (ETM) was allowed to react with cerium (IV) in $\mathrm{H}_{2} \mathrm{SO}_{4}$ medium and gets oxidizing to its sulphoxide.

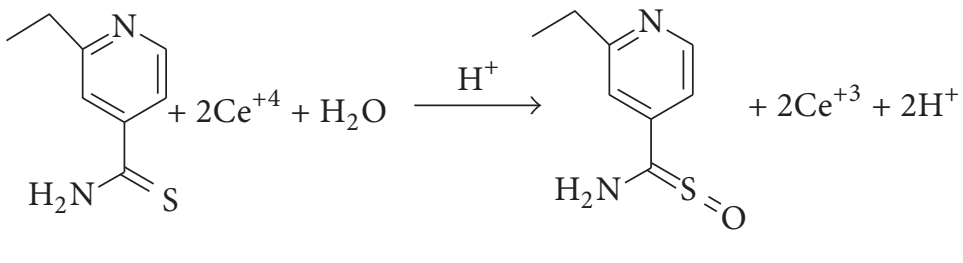

\section{ETM}

After an appropriate reaction time, the residual oxidant was determined by two approaches. In titrimetry, the unreacted oxidant was determined by titration with FAS using ferroin indicator.

$$
\mathrm{Ce}^{+4}+\mathrm{Fe}^{+2} \rightleftharpoons \mathrm{Ce}^{+3}+\mathrm{Fe}^{+3}
$$<smiles>COc1cc(-c2ccc(N)c(OC)c2)ccc1N</smiles>

ETM sulphoxide

The amount of cerium (IV) reacted was related to the amount of drug, and the drug-oxidant reaction followed a 1:2 stoichiometry which served as the basis of the calculations. In spectrophotometry, the unconsumed oxidant was determined by reacting with ODS as shown in (4) and measuring the absorbance of the coloured species of the oxidation product of ODS at $470 \mathrm{~nm}$ (Figure 1).<smiles>COC1=CC(C2C=CC(=[NH2+])C(OC)=C2)C=CC1=[NH2+]</smiles>

Coloured species 


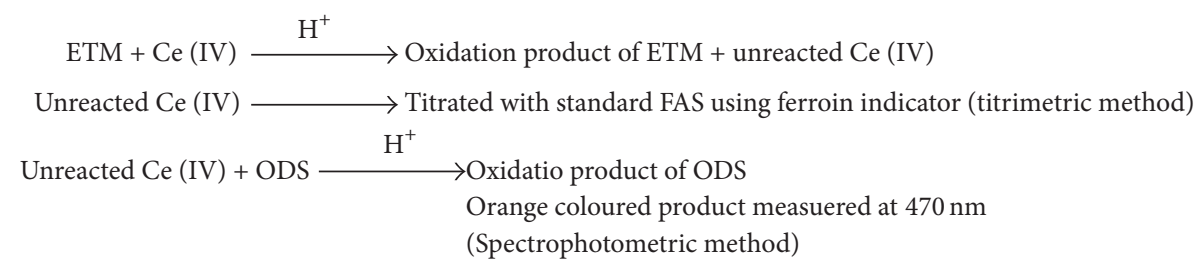

SCHEME 1: The possible reaction pathways and basis of assays.

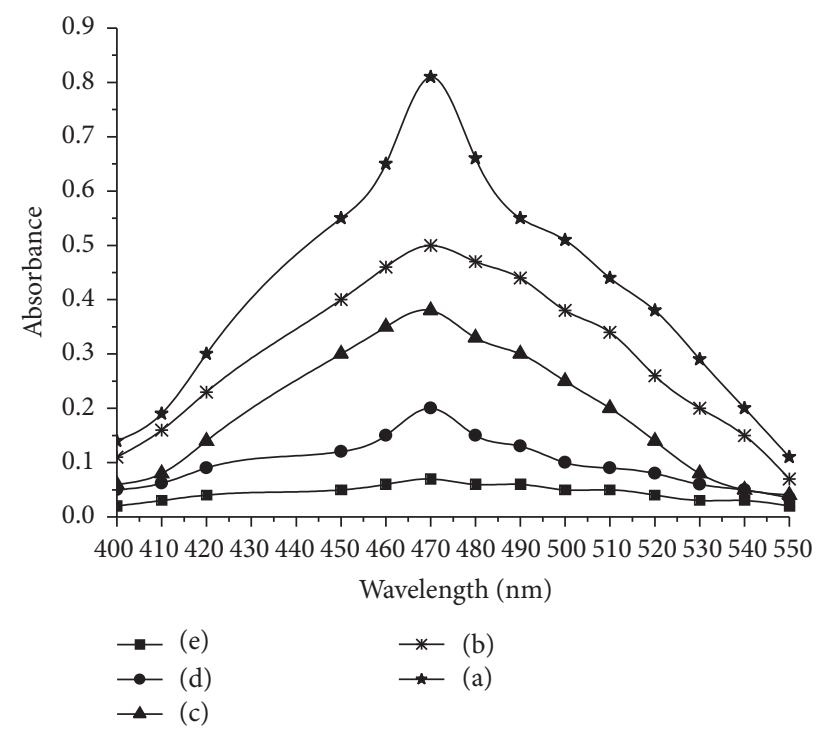

FIGURE 1: Absorption spectra of the reaction product in the presence of (a) 0.0 ; (b) 2.0 ; (c) 3.0 ; (d) 4.0 ; and (e) $5.0 \mu \mathrm{g} / \mathrm{mL}$ ETM; the amount of other reactants remained constant.

The calibration graph is a plot of the difference in absorbance of the reagent blank and sample solution versus the concentration of ETM (Figure 2), and this served as basis for the quantification. The possible reaction pathways and basis of assays are shown in Scheme 1.

In spectrophotometric method, three blanks were prepared. The first blank which contained all reactants except ETM gave maximum absorbance. The second blank contained only $\mathrm{Ce}$ (IV) and $\mathrm{H}_{2} \mathrm{SO}_{4}$. The third blank contained optimum amounts of ODS and acid. Since the last two blanks had negligible absorbance at $470 \mathrm{~nm}$, measurements were made against double distilled water.

3.1. Method Development. Direct titration of ETM with cerium (IV) in different $\mathrm{H}_{2} \mathrm{SO}_{4}$ concentrations was not successful. Back titrimetric assay was possible in the presence of $5 \mathrm{~mL}$ of $2 \mathrm{M} \mathrm{H}_{2} \mathrm{SO}_{4}$ in a total volume of $25 \mathrm{~mL}$ (net, $0.4 \mathrm{M}$ ).

A contact time of $5 \mathrm{~min}$ was found optimum for the range (1-8 mg) studied with $0.01 \mathrm{M}$ cerium (IV) solution. A fixed reaction stoichiometry of $1: 2$ (drug: oxidant) was found for the investigated range of ETM. Beyond these limits $(<1$ and $>8 \mathrm{mg}$ ), slightly inconsistent reaction ratios were obtained.

The ability of cerium (IV) to oxidize ETM and also ODS to an orange-red coloured product was exploited for the indirect
TABLE 1: Sensitivity and regression parameters.

\begin{tabular}{lc}
\hline Parameter & Spectrophotometric method \\
\hline$\lambda_{\text {max }}, \mathrm{nm}$ & 470 \\
Colour stability & $30 \mathrm{~min}$ \\
Linear range, $\mu \mathrm{g} / \mathrm{mL}$ & $0.5-5.0$ \\
Molar absorptivity $(\varepsilon), \mathrm{L} /(\mathrm{mol} \cdot \mathrm{cm})$ & $2.66 \times 10^{4}$ \\
Sandell sensitivity ${ }^{*}, \mu \mathrm{g} / \mathrm{cm}^{2}$ & 0.0063 \\
Limit of detection $(\mathrm{LOD}), \mu \mathrm{g} / \mathrm{mL}$ & 0.013 \\
Limit of quantification $(\mathrm{LOQ}), \mu \mathrm{g} / \mathrm{mL}$ & 0.043 \\
Regression equation, $Y^{* *}$ & \\
Intercept ( $a)$ & 0.0038 \\
Slope $(b)$ & 0.1591 \\
Standard deviation of $a\left(S_{a}\right)$ & $9.89 \times 10^{-2}$ \\
Standard deviation of $b\left(S_{b}\right)$ & $2.18 \times 10^{-2}$ \\
Regression coefficient $(r)$ & 0.9989 \\
\hline
\end{tabular}

${ }^{*}$ Limit of determination as the weight in $\mu \mathrm{g} / \mathrm{mL}$ of solution, which corresponds to an absorbance of $A=0.001$ measured in a cuvette of cross-sectional area $1 \mathrm{~cm}^{2}$ and $l=1 \mathrm{~cm} .{ }^{* *} Y=a+b X$, where $Y$ is the absorbance, $X$ is the concentration in $\mu \mathrm{g} / \mathrm{mL}, a$ is intercept, and $b$ is slope.

spectrophotometric assay. A slightly higher concentration of $\mathrm{H}_{2} \mathrm{SO}_{4}$ was required for the twin oxidation steps involved, and to stabilize the coloured product. The oxidation of drug took somewhat a longer time $(10 \mathrm{~min})$ as compared to titrimetry $(5 \mathrm{~min})$, and a further $5 \mathrm{~min}$ was required to stabilize the oxidation product of ODS, which was stable for the next 30 min thereafter.

\subsection{Method Validation}

3.2.1. Linearity, LOD, and LOQ of Spectrophotometric Method. The absorbance-concentration plot was linear with a good correlation coefficient $(0.9989)$ in the $0.5-5.0 \mu \mathrm{g} / \mathrm{mL}$ range. Sensitivity parameters such as molar absorptivity $(\varepsilon)$, Sandell's sensitivity, LOD, and LOQ along with the slope and intercept of the regression equation are compiled in Table 1. Low values of LOD and LOQ and high value of $(\varepsilon)$ confirm the sensitivity of the method for the determination of ETM in bulk drug as well in drug product.

3.2.2. Accuracy and Precision. Replicate determination of ETM in pure drug solution at three levels was performed on an intraday and interday basis as a part of the accuracy and precision evaluation of the proposed methods. Relative standard deviation (\% RSD), a measure of precision, and 


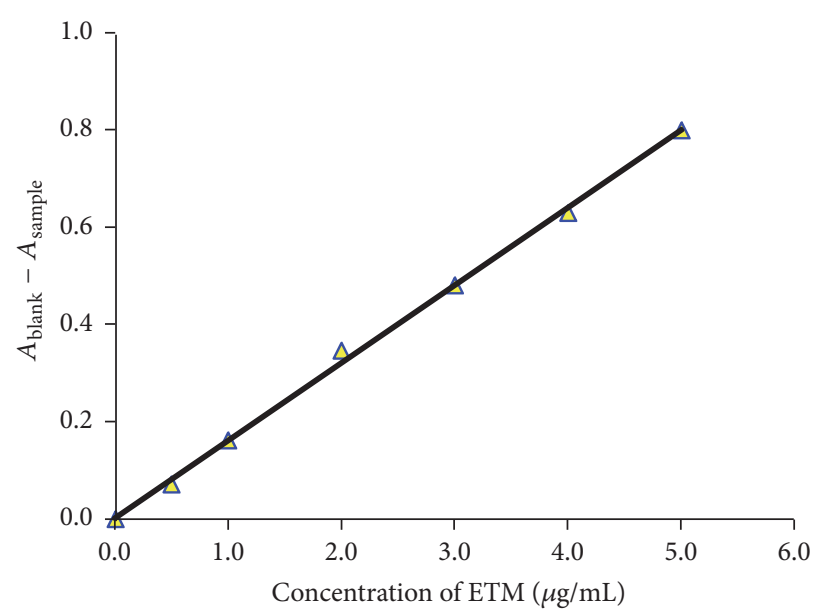

FIGURE 2: Calibration graph.

TABLE 2: Evaluation of intraday and interday accuracy and precision.

\begin{tabular}{|c|c|c|c|c|c|c|c|}
\hline \multirow[b]{2}{*}{ Method } & \multirow[b]{2}{*}{$\begin{array}{c}\text { ETM } \\
\text { taken }(\mathrm{mg} \text { or } \mu \mathrm{g} / \mathrm{mL})\end{array}$} & \multicolumn{3}{|c|}{$\begin{array}{l}\text { Intraday accuracy and precision } \\
\qquad(n=7)\end{array}$} & \multicolumn{3}{|c|}{ Interday accuracy and precision $(n=5)$} \\
\hline & & $\begin{array}{c}\text { ETM } \\
\text { found }^{\mathrm{a}} \\
(\mathrm{mg} \text { or } \mu \mathrm{g} / \mathrm{mL})\end{array}$ & $\begin{array}{c}\mathrm{RSD}^{\mathrm{b}} \\
\%\end{array}$ & $\begin{array}{c}\mathrm{RE}^{\mathrm{c}} \\
\%\end{array}$ & $\begin{array}{l}\text { ETM } \\
\text { found }(\mathrm{mg} \text { or } \mu \mathrm{g} / \mathrm{mL})\end{array}$ & $\begin{array}{c}\mathrm{RSD}^{\mathrm{b}} \\
\%\end{array}$ & $\begin{array}{c}\mathrm{RE}^{\mathrm{c}} \\
\%\end{array}$ \\
\hline \multirow{3}{*}{ Titrimetry } & 2.0 & 2.01 & 1.12 & 0.50 & 1.97 & 1.74 & 1.50 \\
\hline & 4.0 & 3.94 & 1.35 & 1.50 & 4.03 & 2.03 & 0.75 \\
\hline & 6.0 & 6.08 & 1.55 & 1.33 & 6.11 & 1.69 & 1.83 \\
\hline \multirow{3}{*}{ Spectrophotometry } & 1.0 & 0.98 & 1.41 & 2.00 & 1.02 & 1.81 & 2.00 \\
\hline & 2.0 & 1.97 & 1.38 & 1.50 & 2.03 & 1.57 & 1.50 \\
\hline & 3.0 & 3.04 & 1.65 & 1.33 & 2.95 & 1.93 & 1.67 \\
\hline
\end{tabular}

${ }^{a}$ Mean value of seven determinations; ${ }^{b}$ relative standard deviation (\%); ${ }^{c}$ relative error (\%).

relative error (\% RE), an indicator of accuracy values, were calculated to be $\leq 2 \%$ (intraday) and $<2.1 \%$ (interday), as shown in Table 2.

3.2.3. Robustness and Ruggedness. To evaluate the robustness, two experimental variables, namely, contact time and acid concentration, were altered slightly deliberately, and the influence of these changes was studied on the performance of the methods. The performance remained unaffected as shown by small values of $\%$ RSD $(\leq 2.31)$. Determination of drug in solution at three levels was done by using three different burettes in titrimetric method and three cuvettes in spectrophotometric method and also by three persons using the same equipment. The person-to-person and equipmentto-equipment variations did not significantly affect the results as shown in Table 3.

3.2.4. Selectivity. To determine the selectivity of the described methods, placebo and synthetic mixture analyses were performed. Replicate analyses of placebo blank gave a titer value almost equal to that blank titration in titrimetry and absorbance value very much the same as the reagent blank in spectrophotometry. When the synthetic mixture was subjected to analysis, at three amount/concentration levels by the proposed methods, the percent recoveries of pure drug ranged from $99.34 \pm 1.12$ to $101.7 \pm 2.34$ indicating noninterference from the inactive ingredients.

3.2.5. Application to Tablets. Three brands of tablets of $250 \mathrm{mg}$ strength were analyzed by the proposed methods and the results are presented in Table 4 . The same tablets were also analyzed by the reference method [7] for comparison. The results revealed that there is a close agreement between the results obtained by the proposed methods and those of the reference method, besides the label claim. When the results were statistically evaluated by applying Student's $t$ test for accuracy and variance ratio $F$-test for precision, the calculated $t$ - and $F$-values did not exceed the tabulated values at the $95 \%$ confidence level and four degrees of freedom, suggesting that the proposed methods and the reference method have similar accuracy and precision.

3.2.6. Accuracy by Recovery Study. Accuracy of the proposed methods was further confirmed by recovery study following the standard-addition procedure. The percent recovery values of pure drug added shown in Table 5 unambiguously demonstrate that inactive ingredients such as talc, gelatin, starch, 
TABLE 3: Method robustness and ruggedness expressed as intermediate precision (\% RSD).

\begin{tabular}{|c|c|c|c|c|c|}
\hline \multirow{3}{*}{ Method } & \multirow{3}{*}{$\begin{array}{c}\text { ETM } \\
\text { taken }(\mathrm{mg} \text { or } \mu \mathrm{g} / \mathrm{mL})\end{array}$} & \multicolumn{2}{|c|}{ Robustness (\% RSD) } & \multicolumn{2}{|c|}{ Ruggedness (\% RSD) } \\
\hline & & \multicolumn{2}{|c|}{ Parameters altered } & \multirow{2}{*}{$\begin{array}{l}\text { Inter-analysts } \\
\qquad(n=3)\end{array}$} & \multirow{2}{*}{$\begin{array}{l}\text { Interburettes/cuvettes } \\
\qquad(n=3)\end{array}$} \\
\hline & & Contact time* & $\begin{array}{l}\text { Volume of } \\
\mathrm{H}_{2} \mathrm{SO}_{4}{ }^{* *}\end{array}$ & & \\
\hline \multirow{3}{*}{ Titrimetry } & 2.0 & 0.88 & 0.67 & 1.33 & 1.91 \\
\hline & 4.0 & 1.05 & 0.88 & 1.66 & 1.83 \\
\hline & 6.0 & 1.24 & 1.58 & 1.11 & 2.11 \\
\hline \multirow{3}{*}{ Spectrophotometry } & 1.0 & 1.53 & 1.85 & 1.44 & 1.97 \\
\hline & 2.0 & 2.31 & 1.17 & 0.97 & 1.73 \\
\hline & 3.0 & 2.24 & 1.74 & 1.47 & 1.65 \\
\hline
\end{tabular}

In titrimetry, ETM taken/found is in $\mathrm{mg}$ and the same was in $\mu \mathrm{g} / \mathrm{mL}$ in spectrophotometry. ${ }^{*}$ Contact time used: 4,5 , and 6 min in titrimetric method; 8,10 , and $12 \mathrm{~min}$ in spectrophotometric method. ${ }^{* *}$ Volumes of $\mathrm{H}_{2} \mathrm{SO}_{4}$ were 4,5 , and $6 \mathrm{~mL}(2 \mathrm{M})$ in titrimetric method and $2.5,3.0$, and $3.5 \mathrm{~mL}(5 \mathrm{M})$ in spectrophotometric method.

TABLE 4: Results of analysis of tablets by the proposed methods and statistical comparison of the results with the reference method.

\begin{tabular}{|c|c|c|c|c|}
\hline \multirow{3}{*}{$\begin{array}{l}\text { Tablet brand } \\
\text { name }\end{array}$} & \multirow{3}{*}{$\begin{array}{l}\text { Nominal } \\
\text { amount }\end{array}$} & \multicolumn{3}{|c|}{ Found ${ }^{*}(\%$ of nominal amount $\pm S D$ ) } \\
\hline & & \multirow{2}{*}{ Reference method } & \multicolumn{2}{|c|}{ Proposed methods } \\
\hline & & & Titrimetry & Spectrophotometry \\
\hline Ethide & 250 & $100.2 \pm 1.23$ & $\begin{array}{c}99.88 \pm 1.02 \\
t=0.45 \\
F=1.45\end{array}$ & $\begin{array}{c}100.44 \pm 1.86 \\
t=0.24 \\
F=2.29\end{array}$ \\
\hline Ethiokox & 250 & $96.22 \pm 1.45$ & $\begin{array}{c}98.4 \pm 1.71 \\
t=2.17 \\
F=1.39\end{array}$ & $\begin{array}{c}98.06 \pm 2.46 \\
t=1.44 \\
F=2.88\end{array}$ \\
\hline Myobid & 250 & $97.34 \pm 1.54$ & $\begin{array}{c}98.96 \pm 1.85 \\
t=1.51 \\
F=1.44\end{array}$ & $\begin{array}{c}95.84 \pm 1.78 \\
t=1.43 \\
F=1.34\end{array}$ \\
\hline
\end{tabular}

* Mean value of five determinations.

(Tabulated $t$-value at the 95\% confidence level and for four degrees of freedom is 2.78).

(Tabulated $F$-value at the $95 \%$ confidence level and for four degrees of freedom is 6.39).

TABLE 5: Results of recovery experiment through standard-addition method.

\begin{tabular}{|c|c|c|c|c|c|}
\hline Method & Tablet studied & $\begin{array}{l}\text { ETM in tablet (mg; } \\
\qquad \mu \mathrm{g} / \mathrm{mL})\end{array}$ & $\begin{array}{c}\text { Pure ETM } \\
\text { added }(\mathrm{mg} ; \mu \mathrm{g} / \mathrm{mL})\end{array}$ & $\begin{array}{l}\text { Total found (mg; } \\
\qquad \mu \mathrm{g} / \mathrm{mL})\end{array}$ & $\begin{array}{c}\text { Pure ETM } \\
\left.\text { recovered (percent } \pm \mathrm{SD}^{*}\right)\end{array}$ \\
\hline \multirow{3}{*}{ Titrimetry } & \multirow{3}{*}{ Ethide 250} & 2.99 & 1.5 & 4.55 & $101.43 \pm 1.42$ \\
\hline & & 2.99 & 3.0 & 5.92 & $98.97 \pm 0.84$ \\
\hline & & 2.99 & 4.5 & 7.48 & $100.11 \pm 0.68$ \\
\hline \multirow{3}{*}{ Spectrophotometry } & \multirow{3}{*}{ Ethide 250} & 1.51 & 0.75 & 2.33 & $103.22 \pm 2.44$ \\
\hline & & 1.51 & 1.50 & 3.21 & $104.82 \pm 2.53$ \\
\hline & & 1.51 & 2.25 & 3.82 & $102.14 \pm 2.35$ \\
\hline
\end{tabular}

${ }^{*}$ Mean value of three determinations.

magnesium stearate, sodium alginate, and methylcellulose do not interfere in the determination of the active ingredient.

\section{Conclusions}

The oxidation reaction between the ETM and cerium (IV) in acid medium was advantageously exploited for the development of two simple, rapid, cost-effective, and sensitive methods for the determination of ETM in pharmaceuticals. The methods use cheap and easily available chemicals and an inexpensive instrument which can be accessed in any industrial quality control laboratory. The methods employ a stable oxidant unlike the previously reported titrimetric and spectrophotometric methods. Titrimetry is applicable over a micro scale $(<10 \mathrm{mg})$ compared to the reported titrimetric methods including the official method, which would require 300-500 $\mathrm{mg}$ per trial. The proposed spectrophotometric method has a molar absorptivity value of $2.66 \times$ $10^{4} \mathrm{~L} /(\mathrm{mol} \cdot \mathrm{cm})$ with a linear dynamic range of $0.5-5.0 \mu \mathrm{g} / \mathrm{mL}$ and is one of the most sensitive methods ever developed for ETM (Table 6). Hence, the proposed methods can be 
TABLE 6: Comparison of the proposed and the existing spectrophotometric and titrimetric methods for the determination of ETM.

(a) Spectrophotometry

\begin{tabular}{|c|c|c|c|c|c|}
\hline $\begin{array}{l}\text { SL } \\
\text { number }\end{array}$ & Reagent/s & Methodology & $\begin{array}{c}\text { Linear range } \\
(\mu \mathrm{g} / \mathrm{mL})\end{array}$ & Remark & Ref. \\
\hline 1 & DCNQ & $\begin{array}{l}\text { Orange coloured product in } \\
\text { ethanol measured at } 440 \mathrm{~nm}\end{array}$ & - & - & [9] \\
\hline 2 & DCNQ & $\begin{array}{l}\text { Red coloured product formed in } \\
\text { the presence of ammonia in } \\
\text { alcoholic medium measured at } \\
540 \mathrm{~nm}\end{array}$ & $6-42$ & 20 min contact time & [10] \\
\hline 3 & Iron (III) & $\begin{array}{l}\text { Purple-violet colour complex in } \\
\text { acid medium measured at } 510 \mathrm{~nm}\end{array}$ & $0-36$ & $\begin{array}{l}\text { Less sensitive and the molar } \\
\text { absorptivity is equal to } 2.48 \times \\
10^{3} \mathrm{~L} /(\mathrm{mol} \cdot \mathrm{cm})\end{array}$ & {$[11]$} \\
\hline 4 & $\begin{array}{l}\text { Iron (III) } \\
\quad \text { PPD }\end{array}$ & $\begin{array}{l}\text { Thionine compound measured at } \\
\qquad 600 \mathrm{~nm}\end{array}$ & - & $\begin{array}{l}\text { Multiple step reaction } \\
\text { involved }\end{array}$ & {$[12]$} \\
\hline 5 & $\begin{array}{l}\text { Sodium } \\
\text { nitroprusside }\end{array}$ & $\begin{array}{l}\text { Orange coloured product in basic } \\
\text { medium measured at } 510 \mathrm{~nm}\end{array}$ & - & - & {$[13]$} \\
\hline 6 & $\begin{array}{l}\text { Sodium } \\
\text { nitroprusside }\end{array}$ & $\begin{array}{l}\text { Orange-red complex measured at } \\
\qquad 490 \mathrm{~nm}\end{array}$ & $5-32$ & - & {$[14]$} \\
\hline 7 & PAR-V ${ }^{+5}$ & $\begin{array}{c}\text { Ternary complex }(1: 1: 1) \\
\text { extracted into chloroform and } \\
\text { measured at } 560 \mathrm{~nm}\end{array}$ & $0.2-20$ & $\begin{array}{l}30 \text { min contact time, } \\
\text { extraction step is required }\end{array}$ & {$[15]$} \\
\hline 8 & Osmic acid & $\begin{array}{l}\text { Light yellow coloured product } \\
\text { formed at pH4 measured at } \\
\qquad 375 \mathrm{~nm}\end{array}$ & $0.25-40$ & $\begin{array}{l}60 \text { min contact time, } \mathrm{pH} \\
\text { adjustment is required }\end{array}$ & {$[16]$} \\
\hline 9 & NBS-CB & $\begin{array}{l}\text { Unbleached dye colour measured } \\
\text { in acid medium at } 540 \mathrm{~nm}\end{array}$ & $0.2-5.0$ & $\begin{array}{l}\text { Critical acid conc.; less stable } \\
\text { reagent used }\end{array}$ & {$[17]$} \\
\hline 10 & $\mathrm{KMnO}_{4}$ & $\begin{array}{l}\text { Blue coloured manganate in } \\
\text { alkaline medium measured at } \\
610 \mathrm{~nm} \text { (direct method) }\end{array}$ & $1-10$ & $\begin{array}{l}\text { Critical } \mathrm{NaOH} \text { conc. } \\
\text { Reaction rate precariously }\end{array}$ & {$[18]$} \\
\hline & & $\begin{array}{l}\text { Absorbance at a fixed time of } \\
20 \text { min measured (kinetic } \\
\text { method) }\end{array}$ & $1-10$ & $\begin{array}{c}\text { dependent on experimental } \\
\text { variables }\end{array}$ & \\
\hline 11 & $\begin{array}{l}\text { Sodium } \\
\text { azide-iodine }\end{array}$ & $\begin{array}{l}\text { Decrease in absorbance at the } \\
\text { 5th min measured at } 348 \mathrm{~nm} \\
\text { (kinetic method) }\end{array}$ & $10-100$ & $\begin{array}{c}\text { Reaction rate precariously } \\
\text { dependent on experimental } \\
\text { conditions }\end{array}$ & [19] \\
\hline 12 & $\mathrm{Ce}(\mathrm{IV}) / \mathrm{ODS}$ & $\begin{array}{l}\text { Orange-red coloured species } \\
\text { measured at } 470 \mathrm{~nm}\end{array}$ & $0.5-5.0$ & $\begin{array}{c}\text { Nondrastic experimental } \\
\text { conditions, no critical pH } \\
\text { adjust, no heating or extraction } \\
\text { step. Shorter contact time } \\
\text { (15 min), no use of organic } \\
\text { solvent }\end{array}$ & $\begin{array}{l}\text { Present } \\
\text { work }\end{array}$ \\
\hline \multicolumn{6}{|c|}{ (b) Titrimetry } \\
\hline $\begin{array}{l}\text { SL } \\
\text { number }\end{array}$ & Reagent/s & End point detection & Linear range & Remark & Ref. \\
\hline 1 & NBS & Visually & - & Less stable oxidant used & {$[20]$} \\
\hline 2 & $\mathrm{I}_{2}-\mathrm{NaOH}$ & Potentiometrically & $25-500 \mu \mathrm{mol}$ & $\begin{array}{l}\text { Critically dependent on alkaline } \\
\text { concentration }\end{array}$ & {$[21]$} \\
\hline 3 & $\mathrm{AgNO}_{3}$ & Potentiometrically & - & $\begin{array}{l}\text { Preparation of AgS-sensor is } \\
\text { tedious \& cumbersome, } \\
\text { expensive titrant used }\end{array}$ & {$[22]$} \\
\hline 4 & $\mathrm{Ce}(I V) / \mathrm{FAS}$ & $\begin{array}{l}\text { Unreacted } C e^{4+} \\
\text { titrated versus FAS }\end{array}$ & $1-8 m g$ & $\begin{array}{l}\text { Stable titrant used, facile working } \\
\text { conditions employed }\end{array}$ & $\begin{array}{l}\text { Present } \\
\text { work }\end{array}$ \\
\hline
\end{tabular}

DCNQ: Dichloronaphthoquinone; PAR: 4-(2-pyridylazo) resorcinol; PPD: p-phenylenediamine; NBS: N-bromosuccinimide; CB: Celestine blue; ODS: orthodianisidine; FAS: ferrous ammonium sulphate. 
conveniently employed in laboratories which can ill-afford costly chromatographic techniques.

\section{Competing Interests}

The authors declare that there is no conflict of interests regarding the publication of this paper.

\section{Acknowledgments}

The authors are thankful to Panacea Biotec Ltd. for their generous gift sample of ethionamide. Professor Kanakapura Basavaiah wishes to thank the University Grants Commission, New Delhi, India, for the award of BSR faculty fellowship. The author Nagib A. S. Qarah is thankful to the UGC New Delhi, India, for supporting research.

\section{References}

[1] J. E. Conte Jr., J. A. Golden, M. Mcquitty, J. Kipps, E. T. Lin, and E. Zurlinden, "Effects of AIDS and gender on steadystate plasma and intrapulmonary ethionamide concentrations," Antimicrobial Agents and Chemotherapy, vol. 44, no. 5, pp. 13371341, 2000.

[2] V. A. Ongaya, W. A. Githui, H. Meme, C. Kiiyukia, and E. Juma, "High ethionamide resistance in Mycobacterium tuberculosis strains isolated in Kenya," African Journal of Health Sciences, vol. 20, no. 1-2, pp. 37-41, 2012.

[3] J. Crofton, P. Chaulet, and D. Maher, Guidelines for the Management of Multidrug-Resistant Tuberculosis, World Health Organization, Geneva, Switzerland, 1997.

[4] J. S. Blanchard, "Molecular mechanisms of drug resistance in Mycobacterium tuberculosis," Annual Review of Biochemistry, vol. 65 , pp. 215-239, 1996.

[5] K. Takayama, L. Wang, and H. L. David, "Effect of isoniazid on the in vivo mycolic acid synthesis, cell growth, and viability of Mycobacterium tuberculosis," Antimicrobial Agents and Chemotherapy, vol. 2, no. 1, pp. 29-35, 1972.

[6] J. N. Delgado and W. A. Remers, Wilson and Gisvold's Textbook of Organic Medicinal and Pharmaceutical Chemistry, Lippincott-Raven, New York, NY, USA, 10th edition, 1998.

[7] The British Pharmacopeia, Volume I \& II Monographs: Medicinal and Pharmaceutical Substances, Ethionamide, The British Pharmacopeia, London, UK, 2009.

[8] M. I. Walash, A. M. El-Brashy, M. E.-S. Metwally, and A. A. Abdelal, "FLuorimetric determination of carbocisteine and ethionamide in drug formulation," Acta Chimica Slovenica, vol. 51, no. 2, pp. 283-291, 2004.

[9] M. M. Bedair, "Use of 2,3-dichloro-1,4-naphthoquinone for the spectrophotometric assay of five thio compounds of pharmaceutical importance," Alexandria Journal of Pharmaceutical Sciences, vol. 5, pp. 64-67, 1991.

[10] M. B. Devani, C. J. Shishoo, H. J. Mody, and P. K. Raja, "Detection of thioamides: determination of ethionamide with 2,3-dichloro-1,4-naphthoquinone," Journal of Pharmaceutical Sciences, vol. 63, no. 9, pp. 1471-1473, 1974.

[11] A. K. Shah, Y. K. Agrawal, and S. K. Banerjee, "Spectrophotometric method for the rapid determination of microgram amounts of ethionamide," Analytical Letters, vol. 14, no. 17-18, pp. 1449-1464, 1981.
[12] M. S. El-Din, F. Belal, and S. Hassan, "Spectrophotometric determination of some pharmaceutically important thionecontaining compounds," Zentralblatt für Pharmazie, Pharmakotherapie und Laboratoriumsdiagnostik, vol. 127, no. 3, pp. 133-135, 1988.

[13] F. A. Ibrahim, "Colorimetric estimation of certain thionecompounds of pharmaceutical importance," Mansoura Journal of Pharmaceutical Sciences, vol. 10, pp. 334-344, 1994.

[14] M. B. Devani, C. J. Shishoo, and K. Doshi, "A spectrophotometric determination of ethionamide in tablets," Indian Journal of Pharmaceutical Sciences, vol. 43, no. 4, pp. 149-150, 1981.

[15] H. Sikorska-Tomicka, "Spectrophotometric determination of ethionamide and thionicotinamide with 4-(2-pyridylazo) resorcinol and vanadium," Chemia Analityczna (Warsaw), vol. 38, pp. 745-751, 1993.

[16] H. Sikorska-Tomicka, "Spectrophotometric determination of ethionamide and thionicotinamide with osmic acid," Mikrochimica Acta, vol. 87, no. 3, pp. 151-157, 1985.

[17] C. S. P. Sastry, K. R. Srinivas, and K. M. M. K. Prasad, "Spectrophotometric determination of drugs in pharmaceutical formulations with N-bromosuccinimide and Celestine blue," Mikrochimica Acta, vol. 122, no. 1-2, pp. 77-86, 1996.

[18] M. I. Walash, A. M. El-Brashy, M. S. Metwally, and A. A. Abdelal, "Spectrophotometric and kinetic determination of some sulphur containing drugs in bulk and drug formulations," Bulletin of the Korean Chemical Society, vol. 25, no. 4, pp. 517524, 2004.

[19] M. I. Walash, M. E.-S. Metwally, A. M. El-Brashy, and A. A. Abdelal, "Kinetic spectrophotometric determination of some sulfur containing compounds in pharmaceutical preparations and human serum," Il Farmaco, vol. 58, no. 12, pp. 1325-1332, 2003.

[20] B. S. Reddy, R. R. Krishna, and C. S. P. Sastry, “Titrimetric determination of some antitubercular drugs by sodium nitrite and N-bromosuccinimide (NBS) using internal indicators," Indian Drugs, vol. 20, pp. 28-29, 1982.

[21] W. Ciesielski, A. Krenc, and U. Zlłobińska, "Potentiometric titration of thioamides and mercaptoacids with iodine in alkaline medium," Chemia Analityczna, vol. 50, no. 2, pp. 397405, 2005.

[22] S. I. Obtemperanskaya, M. M. Buzlanova, I. V. Karandi, R. Shakhid, and A. N. Kashin, "Potentiometric determination of some drugs and other physiologically active substances using a silver sulfide ion-selective electrode," Journal of Analytical Chemistry, vol. 51, no. 4, pp. 419-423, 1996.

[23] A. I. Vogel, A Textbook of Quantitative Inorganic Analysis, The English Language Book Society and Longman, London, UK, 3rd edition, 1961.

[24] ICH, International conference on hormonisation of technical requirement for registration of pharmaceuticals for human use, ICH harmonised tripartite guideline: validation of analytical procedures: text and methodology Q2(R1), Complementary Guideline on Methodology dated 06 November 1996, incorporated in November 2005, London.

[25] J. C. Miller and J. N. Miller, Statistic for Analytical Chemistry, Ellis Horwood, New York, NY, USA, 4th edition, 1994.

[26] I. A. Darwish, A. S. Khedr, H. F. Askal, and R. M. Mahmoud, "Simple fluorimetric method for determination of certain antiviral drugs via their oxidation with cerium (IV)," Il Farmaco, vol. 60, no. 6-7, pp. 555-562, 2005. 
[27] N. Rajendraprasad, K. Basavaiah, and K. B. Vinay, "Volumetric and spectrophotometric determination of oxcarbazepine in tablets," Acta Chimica Slovenica, vol. 58, no. 3, pp. 621-628, 2011.

[28] H. D. Revanasiddappa, H. N. Deepakumari, and S. M. Mallegowda, "Development and validation of indirect spectrophotometric methods for lamotrigine in pure and the tablet dosage forms," Analele Universitatii din Bucuresti-Chimie, vol. 20, no. 1, pp. 49-55, 2011.

[29] K. Basavaiah, U. Chandrashekar, and H. C. Prameela, "Cerimetric determination of propranolol in bulk drug form and in tablets," Turkish Journal of Chemistry, vol. 27, no. 5, pp. 591-599, 2003.

[30] M. S. Raghu, K. Basavaiah, K. N. Prashanth, and K. B. Vinay, "Titrimetric and spectrophotometric methods for the assay of ketotifen using cerium(IV) and two reagents," International Journal of Analytical Chemistry, vol. 2013, Article ID 697651, 9 pages, 2013.

[31] H. F. Askal, O. H. Abdelmegeed, S. M. S. Ali, and M. A. El-Hamd, "Spectrophotometric and spectrofluorimetric determination of 1,4-dihydropyridine drugs using potassium permanganate and cerium (IV) ammonium sulphate," Bulletin of Pharmaceutical Sciences, vol. 33, no. 2, pp. 201-215, 2010.

[32] K. Basavaiah, O. Z. Devi, K. Tharpa, and K. B. Vinay, "Oxidimetric assay of simvastatin in pharmaceuticals using cerium (IV) and three dyes as reagents," Proceedings of the Indian National Science Academy, vol. 74, no. 3, pp. 119-124, 2008. 

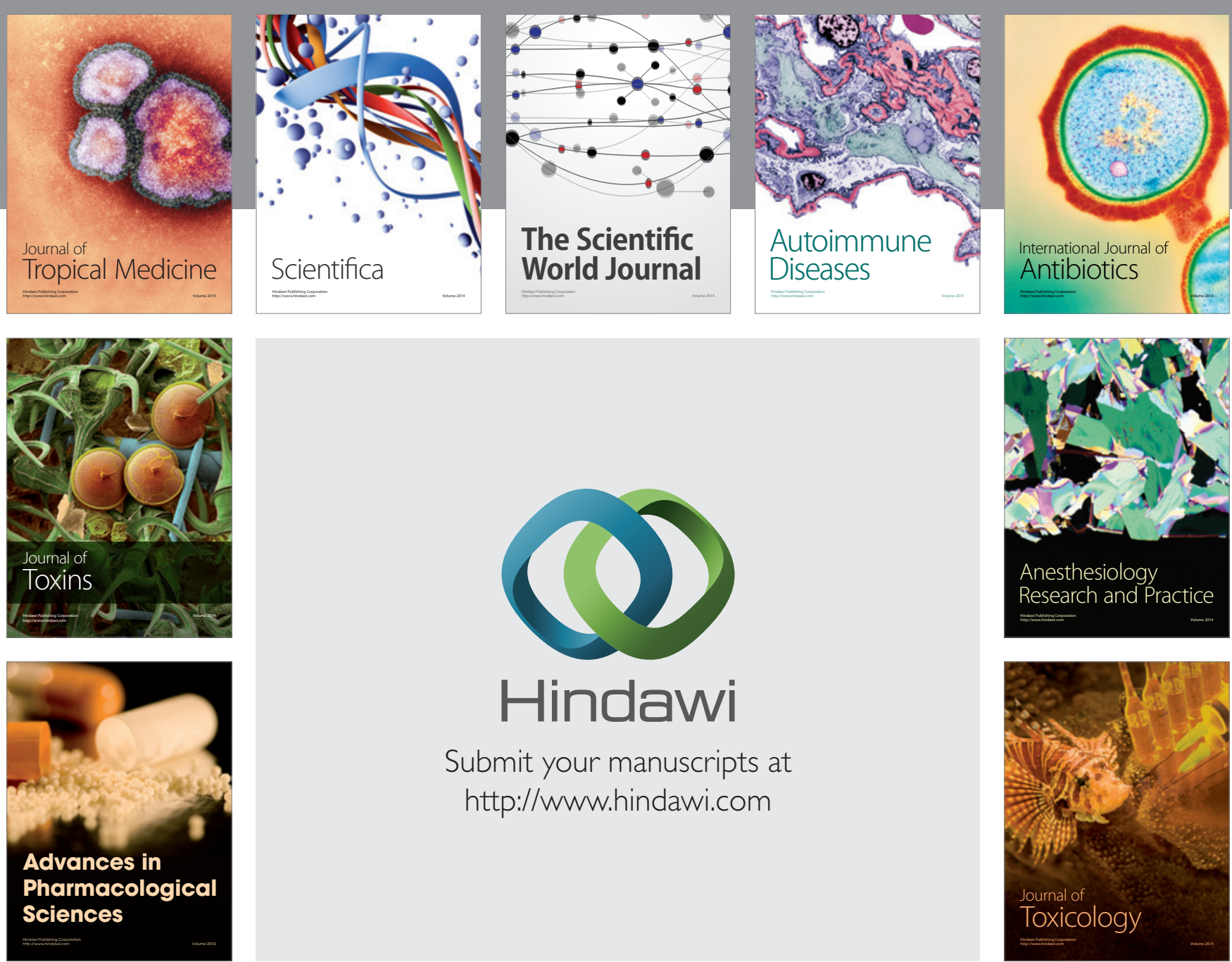

\section{Hindawi}

Submit your manuscripts at

http://www.hindawi.com
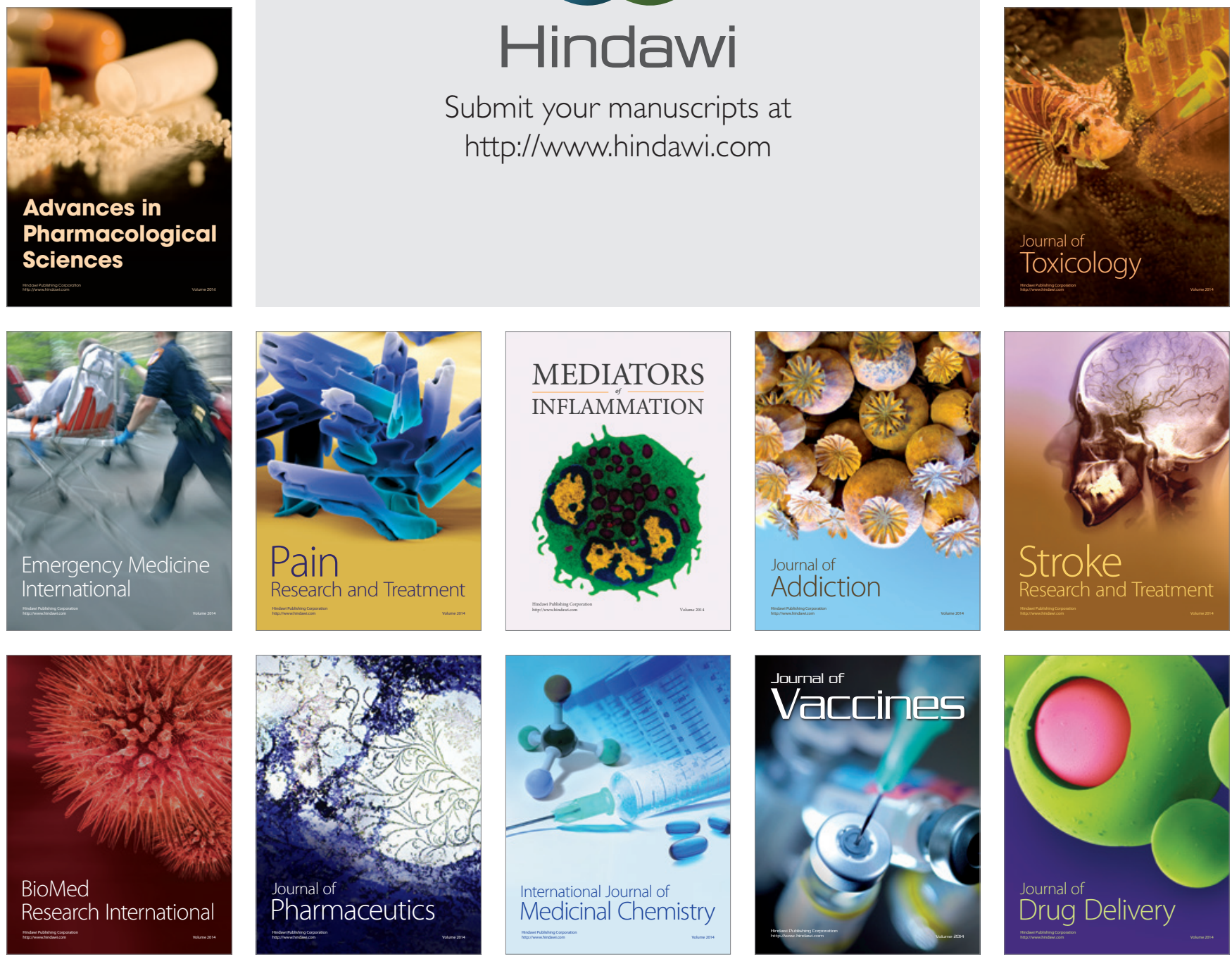